\title{
STRUCTURAL AND STRESS ANALYSIS IN MINING PRACTICE IN THE UPPER SILESIAN COAL BASIN
}

\author{
Petr WACLAWIK ${ }^{1)}$, Jiř́i PTÁČEK ${ }^{2) *}$ and Radomír GRYGAR ${ }^{3)}$
}

\author{
1) OKD, a.s., ČSM Mine, 73534 Stonava 1077 \\ 2) Institute of Geonics, Czech Academy of Sciences, v. v.i., Studentská 1768, 70800 Ostrava Poruba \\ 3) Institute of Geology, Faculty of Mining and Geology, VŠB-Technical University of Ostrava, 17. listopadu 15, \\ 70800 Ostrava Poruba \\ *Corresponding author's e-mail: ptacek@ugn.cas.cz
}

(Received July 2012, accepted January 2013)

\begin{abstract}
The irregular distribution of stress in rock mass is a decisive factor for the origin of rock bursts. Besides, a sound knowledge of stress distribution is very important in the excavation of mine workings. Stress state is affected both by natural stress, including the gravitational, tectonic, hydraulic and residual stress and the stress induced by mining operations. Natural stress fields are defined by their geological structure and rock properties. It is important in mining practice to understand that there is a close relationship between recent and residual tectonic stress, as defined by tectonic evolution and tectonic structure. Since 1994, a large number of horizontal stress measurements have been carried out at a depth of $600 \mathrm{~m}$ to $800 \mathrm{~m}$ under the surface. The application of the results obtained from the measurements of stress and their comparison with the results of structural analysis and their generalization for the Karviná subbasin can be an important contribution to optimize the timespace designs of the mining activity.
\end{abstract}

KEYWORDS: horizontal stress, structural analysis, mine roadway stability, coal mining, rock burst

\section{INTRODUCTION}

Stress fields and their distribution in rock mass significantly affect the stability of mine workings. In addition to the fact that the irregular distribution of stress in rock mass is a decisive factor for the origin of rock bursts, a sound knowledge of stress distribution is also important in the excavation of mine workings. Stress state is affected both by natural stress, including the gravitational, tectonic, hydraulic and residual stress and the stress induced by mining operations. While induced stress can be controlled, to a certain extent (e.g. by right time and spatial design of the mine workings excavation), primary stress fields are defined by their geological structure and rock properties and their control is limited. The effect of the vertical stress component is generally known and is a factor taken into consideration in the design of mine workings. The effect of horizontal stress components on a mine working, and on its support is less used in coal mining. A mine working can be deformed differently, depending on the differing orientation toward the horizontal components of stress. Knowledge of stress distribution is necessary for an optimum design of excavation methods and rock burst prevention. Since 1994, a large number of horizontal stress measurements have been carried out at a depth of $600 \mathrm{~m}$ to $800 \mathrm{~m}$ under the surface. In addition to the measurements using the hydro- fracturing method, several measurements were also carried out using the overcoring method (Compact Conical End Borehole Overcoring - CCBO). It is important in mining practice to understand that there is a close relationship between recent and residual tectonic stress, as defined by tectonic evolution and tectonic structure. Residual tectonic stress can, to a certain extent, be interpreted on the basis of tectonic analysis. The application of the results obtained from the measurements of stress and their comparison with the results of structural analysis and their generalization for the Karviná subbasin can be an important contribution to optimize the time-space designs of the mining activity.

\section{BRIEF SUMMARY OF THE TECTONIC STRUCTURE AND STRESS CONDITIONS IN THE KARVINÁ SUBBASIN}

The Karviná subbasin represents a partial structure of the Upper Silesian Coal Basin bounded by the Orlová fold structure in the West. This part corresponds tectonically to the lowest sunken region of the Czech part of the Upper Silesian Coal Basin. Actually, the Karviná subbasin has the simplest tectonic structure within the known Czech part of the Upper Silesian Coal Basin. In this area of the basin, the normal fault structures combined with the horizontal component of displacement and the 


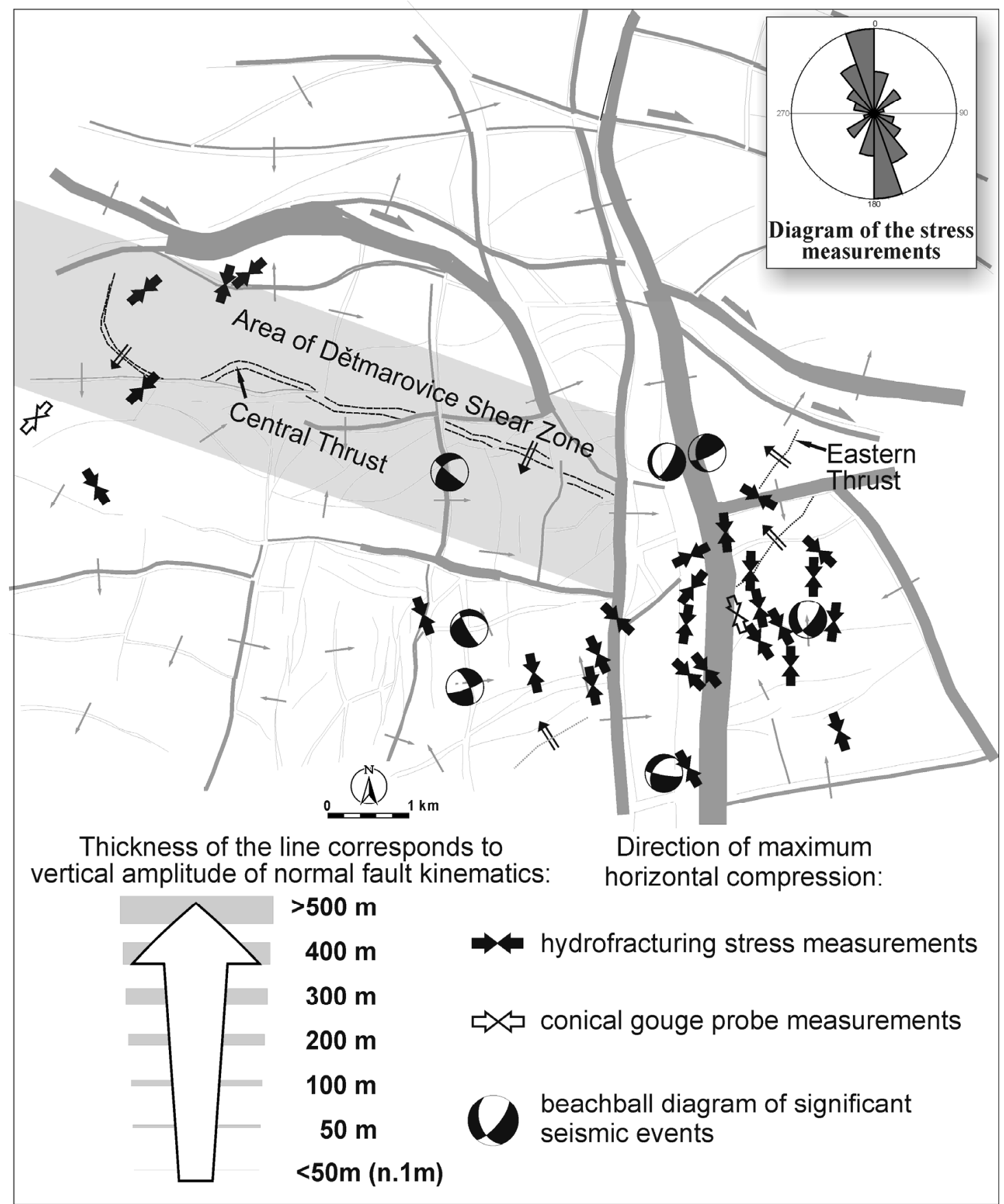

Fig. 1 Synoptic structural map of major faults in the Karviná part with the demarcation of the position of a zone of Central Thrust and a zone of Eastern Thrust, supplemented with stress measurements (Ptáček et al., 2012).

significant thrust structures with a relative horizontal displacement to the order of hundreds of meters are encountered. These thrust structures form a complicated compression system defined as the Central Karviná Thrust and newly confirmed Eastern Thrust. With regard to its character and extent, it can be classified as the important anomalous structural phenomenon in the Karviná subbasin (Ptáček, 1999; Grygar and Waclawik, 2006). From the tectonic point of view, the Karviná subbasin can be characterized as the apical zone of the Variscan accretionary wedge - basin foreland (e.g. DeCelles and Giles, 1996) where, especially in final phases of the Variscan tectonic genesis, prevailed the transtensional stress mode. The result is a tectonic style, where the normal fault character with the strike slip component of the movement predominates over the compression, overthrust structures (Kumpera, 1980; Grygar et al., 1989; Kumpera and Martinec, 1995). Overthrust structures are the best indicator of the orientation of horizontal components of paleostress and therefore usually of recent residual tectonic stresses. This is also 
confirmed by the measurement of recent stress conditions by the hydrofracturing method or by the modified overcoring method (Compact Conical End Borehole Overcoring - CCBO) (Staš et al., 1997, 1999, 2002, 2003).

Previous research resulted in the concept of one single extensive overfault structure in Karviná subbasin (Ptáček, 1999). According to this concept, the original, Northern branch of the overthrust structure and confirmed in the exploited areas of the Karviná Mine - the localities of the Doubrava and ČSA mines were interconnected with the overthrust verified later in the exploited eastern part of the coal basin, i.e. in the Darkov and ČSA mines.

On the basis of comprehensive analysis of structural data, maps and primary documentation, Grygar and Waclawik (2006) modified this relatively simplified idea based on one single regional overthrust structure. The originally defined zone of the western, and/or northern overthrust in the Karviná coal basin (the localities of the Doubrava and ČSA mines); i.e. the originally demarcated zone of Central Thrust (Grygar et al., 1989; Ptáček et al., 2009) does not form a connected zone with Eastern Thrust in the exploitation spaces in the Darkov and ČSM mines. Therefore, two mutually conditioned structures, which are independent spatially, but close to each other from the genetic and time aspects, were newly defined. There is the newly defined zone of the Eastern Thrust and Central Thrust (see Fig. 1).

\subsection{ZONE OF EASTERN THRUST}

The general course of the zone of Eastern Thrust leads in a northwest and southwest direction. Within the zone of the Eastern Thrust, the thrust traces in the seams oriented initially NNE-SWS rotate to southwest into the direction WSW-ENE. That means that they are parallel with the orientation of major regional thrust-fold structures of the Upper Silesian Coal Basin (the Orlová-Buguszovice structure, the Michálkovice structure, etc.). The Eastern Thrust is not a simple plane with constant spatial geometry. The course of inclination of this structure is especially variable. Flat thrust planes, often intrabed dislocations and further the significant tectonic ramps (the systems of thrusts of a "ramp" and "flat" type are typical (e.g. Pluijm and Marshak, 1997). The "shears" occur on these ramps, in the majority of cases along a steeper thrust area, where the shear stress accumulates. Thrusts subsequently continue in intrabed slips. The intrabed slip in the seam itself or in the close vicinity of a seam causes anomalous deformations similar to boudinage and other accompanying phenomena. In some sections, the faulting of a coal seam occurs and the thickness of a coal seam is enlarged. In contrary to the other sections, the coal seam is "rolled out" and the thickness is reduced. These deformations have typical features of an early, synlithification deformation of the plastic stadium (Grygar and Waclawik, 2006).
The total verified length of the Eastern Thrust zone is almost $7 \mathrm{~km}$ while the width in the horizontal projection reaches up to $3 \mathrm{~km}$ (Waclawik, 2009). From the structural maps and from the mine documentation collected, a gradual reduction of an amount of transport on the thrust planes from the lower stratigraphic levels into the overlying strata is apparent. The partial overthrust of the Eastern Thrust zone shows a significant growth in the amplitude to the underlying strata varying from the decimeters in the stratigraphic level of the seam 23 up to the tens of meters. The maximum amplitude of $20 \mathrm{~m}$ was recorded in the seam No. 39 in the Darkov Mine. This phenomenon can be explained by a presence of intrabed slips and in general, by total strip thrust in the vicinity of the apical part of the Variscan accretionary wedge by its overthrusting the brunovistulicum (e.g. Grygar et al., 1989; Ptáček, 1999; Grygar and Waclawik, 2006). A growth of the vertical displacement on the thrusts in the northeast direction is also apparent. This trend is the result of significantly greater compression of the Karviná subbasin within the Détmarovice shear zone and in the north direction from this zone (e.g. Grygar et al., 1989; Ptáček, 1999; Grygar and Waclawik, 2006). The orientation of the Eastern Thrust correlates with main overthrust structures and follows an identical trend of intensity deformations to the NNE direction. This proves the genetic relationship with the origin of Eastern Thrust and the evolution of main overthrust structures in the Upper Silesian Coal Basin. The evolution of the Orlová structure further supports this relationship (see Fig. 1).

\subsection{ZONE OF CENTRAL THRUST}

The zone of Central Thrust is generally oriented in the WNW - ESE direction. However, in the area of Doubrava mine, the zone turns sharply to the NNE $\mathrm{SSW}$; i.e. in the direction of the Orlová structure.

The course and the character of the Central Thrust zone have the features of the Eastern Thrust structure. In the horizontal projection, the zone of Central Thrust reaches a width of up to $2.5 \mathrm{~km}$. The total length of the zone in the Karviná subbasin is almost $10 \mathrm{~km}$ (Waclawik, 2009). Also in the case of Central Thrust, the intrabed slips play a crucial role in the mechanism of compression deformation (Grygar and Waclawik, 2006). Similarly to the Eastern Thrust zone, a significant drop of the vertical displacement can be observed varying from meters up to the tens of meters and reducing to decimeters in the direction towards the younger strata sequences. The maximum amplitude of the thrust and the maximum thrust deformations exceed $50 \mathrm{~m}$ in the area of Doubrava mine. Compared to the zone of the Eastern Thrust, the size of the horizontal displacement of the Central Thrust is decreasing in the East-South-East direction. The mutual relationships between the Central and Eastern thrusts, can be observed in the Darkov mine. 
While the Central Thrust zone disappears, the vertical displacements of the Eastern Thrust reach the highest values.

Unlike the genesis of the Eastern Thrust genetically associated with the evolution of the main overthrust structures in the Upper Silesian Coal Basin the evolution of the Orlová structure, the clarification of the formation of Central Thrust is more comprehensive and complicated. The transversal position of the central thrust is atypical with regard to the orientation of the Orlová structure and not only within the Upper Silesian Coal Basin, but within the whole Moravian-Silesian zone (Grygar and Waclawik, 2006). The anomalous position of the Central Thrust probably relates to the dextral Détmarovice shear zone (see Fig. 1). This shear zone separates the region of structurally higher blocks of the Karviná part of the coal basin (the localities of Dukla, Lazy, Darkov and ČSM mines) from the structurally clinched transversal depression of Karviná. Besides the strike dextral component, the Détmarovice zone has the character of flexure disturbed by the system of transcurrent faults (the Détmarovice fault, the Eleonora fault, the Žofie and the Jindrich faults). In this way, the vector sum of transpression component of stress (e.g. Schreurs and Colleta, 2002), derived from the dextral strike slip, leads to an anomalous rise in the inner (stratigraphically lower) zone of the flexure. During the early stage of the late Variscan compressive deformations, the Détmarovice shear zone could behave as the accommodation zone above the structural ramp of the underlying strata (e.g., Calassou et al., 1993; Wilkerson et al., 2002). It compensated kinematic and deformation differences between the northern, more mobile segment and the southern, more stable segment of the Karviná subbasin. Its accommodation function was associated with the significantly higher compression and the Eastvergency movement of the northern section in the Czech part of the Upper Silesian Coal Basin into the subsiding Karviná transverse depression (Grygar and Waclawik, 2006). In a certain sense, the deformation phenomenon of tectonic extrusion is encountered here in the region with a greater subsidence (e.g., Ratschbacher et al., 1991).

As is apparent from Figure 1, the present interpretation of horizontal stresses, based on the results from the measurement of hydro-fracturing and seismic monitoring and illustrated by means of the arrows and beach ball diagrams in Figure 1, corresponds to a course of both branches of Central and Eastern Thrust. Although there are not enough measurements, it is possible to assume, that the orientation of principal stress of the Variscan tectogenesis is preserved and contributes significantly to the total stress conditions in the rock mass of the Karviná part of the coal basin. To a certain extent, this correspondence can be used in planning and designing of mine activities, as shown in the following examples.

\section{POTENTIAL INFLUENCE OF RESIDUAL TECTONIC STRESSES ON THE TIME-SPATIAL LAYOUT OF MINE WORKINGS}

In many cases, the residual tectonic stress in the vicinity of a fault structure can be taken as an important element affecting the resulting stress field in rock mass. Exploitation in the vicinity of these structures can redistribute the stress fields in their vicinity and thus the stress relieved in one segment can increase the stress in adjacent segments. This behavior can be shown in the example of exploitation and occurrence of anomalous phenomena of stress relieving - rock burst in the intersection between two faults, mutually of orthogonal directions, the Hlubina and the Eleonora faults. The exploitation in the vicinity of these structures causes stress redistribution in the wider regions. The release of stress in these structures also causes the redistribution of the stress and stress concentration in adjacent areas.

The rock burst occurred during two consecutive days, firstly in the southeastern block (face 14 036) in the intersection between the Eleonora and the Hlubina fault and subsequently in the northwestern block (face 14070 ) of the same structure (see Fig 4). The recorded rock burst seismic activity was available to analyze the mechanism and origin of the rock burst. (Fig. 2). These analyses were processed by the laboratory of the Seismic Network of Greengas DPB. The statistical diagram of the recorded pole shear planes (Fig. 2 left), along which the movement occurred in the focal area during the rock burst, indicate a very different system with respect to the orientation. This is quite common with intensive seismic phenomena. However, from the statistical viewpoint, the shear planes roughly parallel with a working face are most significant, as are the shear planes in the northeast direction; i.e. parallel with the subsidiary tectonic dislocation running probably inside a small pillar, which was left here, and running parallel with the Hlubina fault. The statistical diagram of the recorded shear planes poles during the second phenomenon is outlined more sharply (Fig. 2, right). From the statistical viewpoint, the most significant shear planes are the shear planes approximately oriented in the North-South direction, i.e. parallel with the Hlubina fault and the shear planes in the east-west direction. This could suggest an important influence of the residual Variscan tectonic stresses.

Stress fields in the Czech part of the Upper Silesian Coal Basin, i.e. also in the Karviná subbasin, are primarily affected by the Variscan mountain building movements. Generally, the west-east orientation of a main component of horizontal stress $\sigma_{1}$ is assumed and at the same time, it was concluded from the structural-tectonic analyses and studies, that an amount of this component decreases to the North in the Upper Silesian Coal Basin. This results in the right-side rotation of force fields, by virtue of which strike movements occur along the West-Eastern faults. The resulting deformations of rock blocks during such 


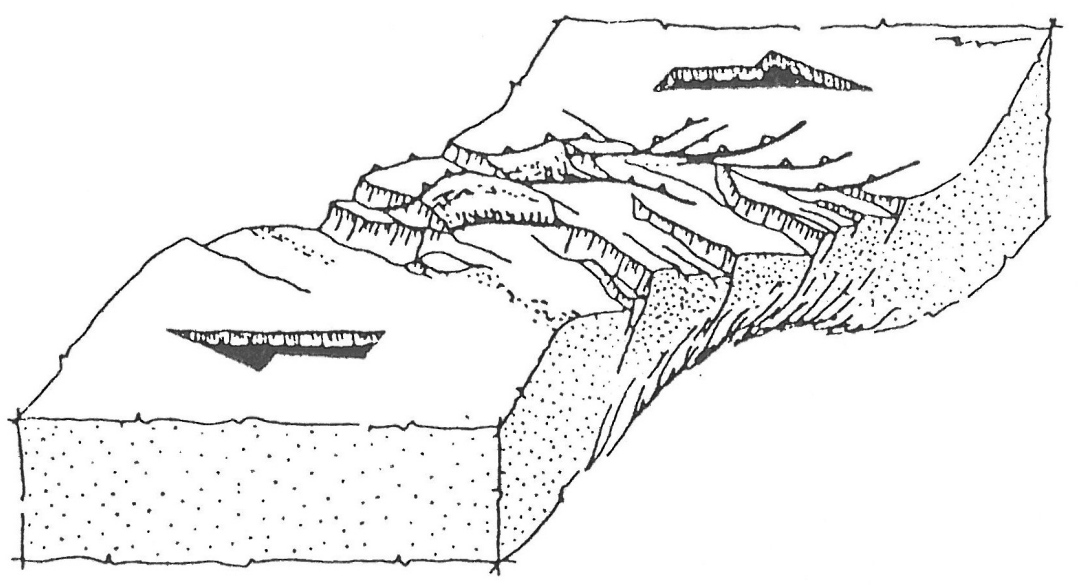

Fig. 3 Block diagram of shear deformation in the right-side rotated stress field.

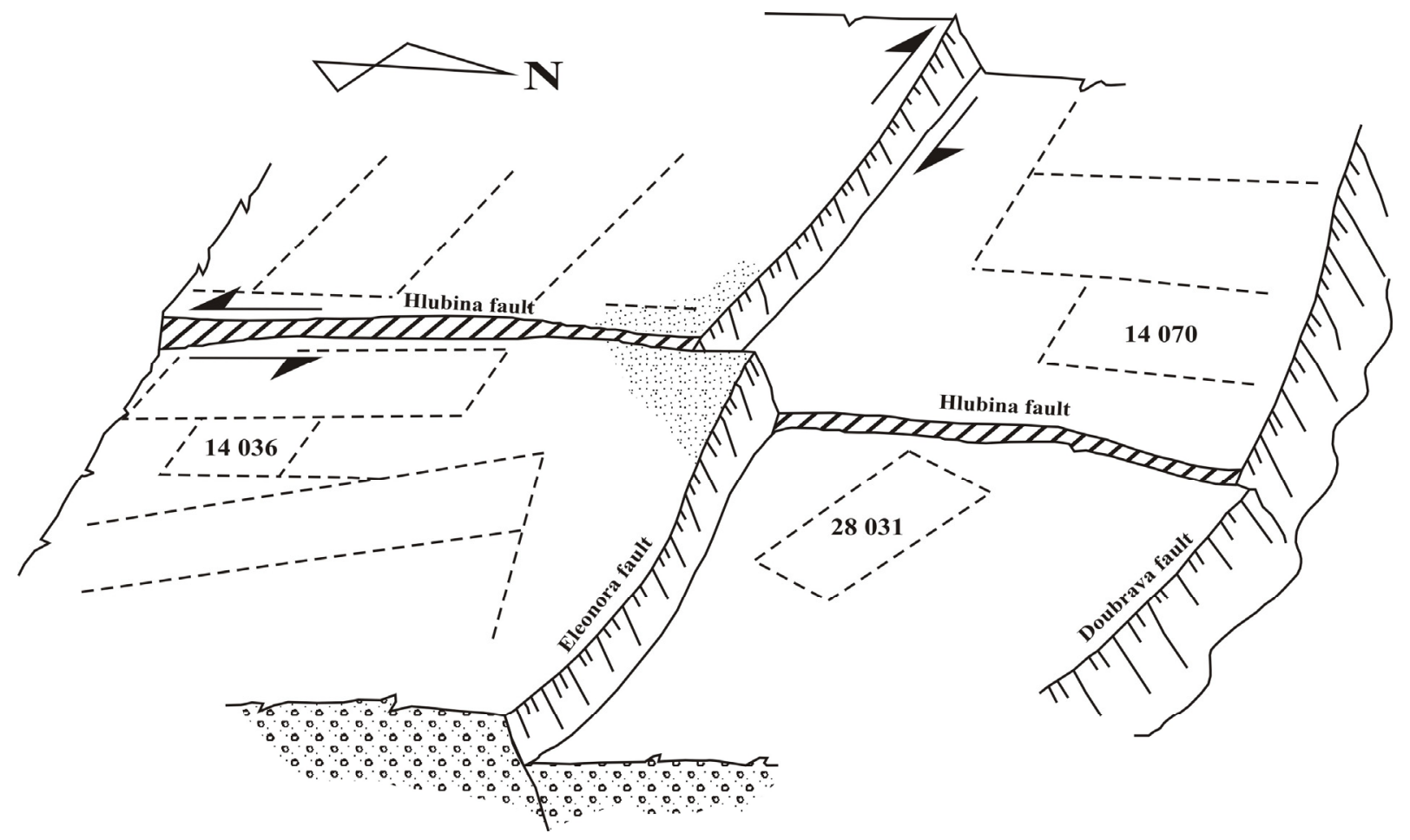

Fig. 4 Block diagram of the area in the block 4 and 8, the Jan Karel Mine and the block 1 and 4 in the Doubrava Mine at a level of the seam 40.

movements are illustrated in the block diagram in Figure. 3.

Complicated stress conditions occur in the zones where the north-south systems of dislocation crossing the west-east system. So called "hinged corner structures" are encountered with a potential tendency to compensate gravitationally a non-uniform stress state. Figure 4 shows these structures as dotted. The exploitation in the vicinity of these structures causes the disturbance of temporary stress equilibrium in such regions. Therefore, the redistribution of stress in these structures also causes the redistribution of stress in their vicinity. Moreover, stress relieving in one segment of the rock mass increases the stress in adjacent segments.

Figure 4 suggests an idea, how residual tectonic stresses participated in its total distribution in the region of the intersection between the Eleonora and 
the Hlubina fault. In order to get a better view of the illustration, the north is turned by $90^{\circ}$ clockwise. The dextral strike slip dislocation of the blocks along the Eleonora fault is assumed (see Fig. 4). Horizontal movements along the Hlubina fault are the reaction to these movements. Both movements are illustrated with bold opposite arrows. In addition, the northeastern corner and northwestern corner of this structure (dotted in Fig. 4) represent the "hinged corner structures" with the stress mechanism described in the previous chapter; i.e. with a potential attempt to compensate the gravitational balance of stress. All these residual stresses can contribute to present movements on fault planes, as similarly encountered on a large scale on large structural faults during earthquakes. The mutual relationship, i.e. loading one block, when the adjacent block is relieved, is also experienced in current exploitation in block 4 in the Jan-Karel Mine (SE structure corner) and in block 4 in the Doubrava Mine (SW structure corner), primarily in the formerly excavated seam 37 . These conclusions are also confirmed by the intensity and released seismic energy, primarily during the event on $14^{\text {th }}$ July 2011 with the magnitude of 2.54 and emitted energy of $8.3 \times 10^{6} \mathrm{~J}$. Such rock bursts were formerly called tectonic rock bursts, which better express the character of these types of rock burst in the northwestern segment of the structure, where coal face 14070 was excavated.

It is not possible to answer unambiguously whether or not a direct relationship between both rock bursts exists. However, the interactive relationships between stress fields in the region of the intersection of tectonic structures, as they have been described above, are one of the causes of these rock bursts and it may be assumed that this cause is very significant. Although these effects are given by the geological structure or rock mass, the danger of the rock burst occurrence can be significantly reduced by appropriate time-spatial design of the exploitation in the vicinity of such geological structures.

\section{RELATIONSHIPS BETWEEN THE DIRECTION OF THE HORIZONTAL STRESSES WITH RESPECT TO THE ORIENTATION OF LONG MINE WORKINGS AND THEIR STABILITY}

Experience in driving of mine workings shows a mutual relationship between the direction of the maximum horizontal stress $\left(\sigma_{\mathrm{H}}\right)$ with respect to the orientation of the drivage of mine workings or the orientation of a working face. The inappropriate driving of a mine working against $\sigma_{\mathrm{H}}$ can have a negative effect on the stability and convergence of the supports in a mine working or in a face being excavated; the stability of the floor; the character of jointing of adjacent rocks and particularly on the unfavorable concentration of stress in the vicinity of mine workings.

In the ground plan shown in Figure 5 is the mathematical model of the stress distribution on the driving face driven parallelly to the maximum horizontal stress. Figure 6 illustrates the opposite situation when mining roadways perpendicular to the maximum horizontal stress component. The difference between stress distribution on face conditions is obvious. While the stress in the first model (Fig. 5) is concentrated in the both edges of the face, the stress relief occurs in the central part of the face. In the case of driving perpendicular to the maximum horizontal stress component (Fig. 6), high stress concentration is distributed evenly on the face. The higher stress magnitude in the second case is evident. Obvious difference is between the magnitudes of horizontal stress at the face.

Experience from a working field in the ČSM mine shows that mine roadway driven at certain directions are subjected to more extensive deformations, while mine workings driven under similar conditions, but differently oriented, are relatively stable. It is shown that a more appropriate orientation of a driving is approximately parallel with $\sigma_{\mathrm{H}}$; i.e. in accord with the previous assumptions about stress conditions in the Karviná part of the coal basin, oriented roughly in the direction NNW-SSE. When a mine working is excavated perpendicularly to the maximum horizontal stress; i.e. parallel to the minimum component of horizontal stress, the mine workings are usually more deformed. In the example of the drivage in seam 40 in the ČSM mine, we want to demonstrate a specific case of such a different deformation encountered in the differently oriented roadways (see Fig. 7).

The roadway 401 290/1 was driven in order to establish the first air connection between the levels at $-630 \mathrm{~m}$ (level 4) and at $-800 \mathrm{~m}$ (level 5) at a level of the seam $39 \mathrm{a}$ and 40 . The drivage started in the seam 40 with an approximate seam thickness of $4 \mathrm{~m}$. Immediately after the commencement of drivage, seismic activity increased in the whole region and a number of seismic phenomena were recorded (Kubica and Klimša, 2007). Many seismic phenomena were demonstrated by dynamic bumps in the roadway. The floor lifted and the roof broke and not least, the energy released during the seismic phenomenon was manifested by rock burst (Kubica and Klimša, 2007). In the same area many roadways were subsequently driven under similar conditions for example, the roadways $401323,401343,401325$ but neither anomalous roadway deformation nor increased seismic activity was recorded. However, these mine workings were oriented approximately perpendicular to the mine working 401290/1.

As this occurence of different stress and deformation behaviour of differently oriented mine workings was observed in many cases, in our opinion, one of the causes of the increased seismic activity and increased deformations of mine workings can be seen in the orientation of driving operations against the maximum horizontal stress. The mine working $401290 / 1$ was driven approximately in a perpen- 
dicular direction to the maximum horizontal stress and on the contrary, all the above mentioned mine workings were driven approximately parallel to the maximum horizontal stress.

These conclusions concerning the orientation of mine workings with regard to the orientation of horizontal stress are not new in mining practice. Similar experience with the orientation of mine workings against horizontal components of stress was gained, for example, in mines in Australia, South Africa or in the Kellingley, Thoresby and Daw Mill mines of UK Coal in Great Britain. Also in the Ostrava-Karviná Coalfield the methodology of the coalface orientation with regard to the texture of rock mass was applied in the past (Dopita et al., 1965; Brieda et al., 1975). Systematic structural measurements were therefore carried out in the mines. In our opinion, even today, appropriate orientation of mine workings can avoid large deformations and/or reduce unfavorable concentrations of stress leading to dynamic phenomena in mine workings.

\section{CONCLUSION}

Stress fields are undoubtedly one of the most important factors affecting mining activities. The experience with relieving the stress at excavation of mine workings in the easternmost section of the Karviná subbasin and the experience with the influence of residual tectonic stresses in the intersection of faults, suggests a mutual relationship between the time-spatial excavation of mine workings and the orientation of the stress tensor components. In order to generalize such interpretations, it is necessary to supplement the measurement of recent stresses carried out in the Ostrava-Karviná Coalfield, because the present network of measurements is infrequent and unequal. Thanks to sound knowledge of stress conditions at the excavation of mine workings, it is possible to optimize appropriately their projection and to contribute to the improved safety and productivity of extraction.

\section{REFERENCES}

Brieda, J., Kumpera, O., Sivek, M. and Tomis, L.: 1975, An essay of the basic ruptures and their sytems in Karviná part of Upper Silesian Coal Basin. Časopis Slezského Musea Opava, Série. A, 24, 97-108, (in Czech).

Calassou, S., Larroque, C. and Malavieille, J.: 1993, Transfer zones of deformation in thrust wedges: an experimental study. Tectonophysics, 221, 325-344. DOI: 10.1016/0040-1951(93)90165-G

DeCelles, P.G. and Giles, K.A.: 1996, Foreland basin systems. Basin research, 8, 105-123.

Dopita, M., Pták, J. and Škvor, V.: 1965, Handbook of the tectonics in the coal deposits, Ostravsko-karvinské doly, oborové ředitelství, Ostrava, 1-57, (in Czech).

Grygar, R., Adamusová, M., Doležalová, J. and Kalendová, J.: 1989, Structural position and paleodynamic development Upper Silesian Coal Basin with regard to rock burst risk. Sborník. věd. prací Vysoké školy báňské v Ostravě, řada. hor. geol., 1, 39-84, (in Czech).
Grygar, R. and Waclawik, P.: 2006, Structural analysis of the Karviná subbasin (Upper Silesian Coal Basin) regarding to seam exploitation in the depth more than $800 \mathrm{~m}$ under the surface. Final report of the Grant solution GAČR 105/04/0884, VŠB-Technická univerzita Ostrava, Hornicko-geologická fakulta, Institut geologického inženýrství, Ostrava, (in Czech).

Kubica, P. and Klimša, P.: 2007, Experiences with the roadways Nos. $401290 / 1$ and 401282 driving in the depth of 908 and 1078 respectively in $2 b$ block in the ČSM-South Mine. Traditional International Colloquium on Geomechanics and Geophysics, Ostravice, 66-75, (in Czech).

Kumpera, O.: 1980, Structural and Geotectonic Zonality of the Moravo-Silezian Carboniferous (Bohemian Massif). - VII. Congr. Int. Strat., Geol. Carboniferous., Moscow, C. R. 6, 191-198.

Kumpera, O. and Martinec, P.: 1995, The development of the Carboniferous accretionary edge in the MoravianSilesian Paleozoic Basin. J. Czech Geol. Soc., 40, 1-2, $47-64$.

Pluijm, A. and Marshak, S.: 1997, Earth Structure an Introduction to Structural Geology and Tectonics. The McGraw-Hill Companies, Inc., United States of America.

Ptáček, J.: 1999, Influence of tectonic factors on rock burst risk in the Ostrava Karviná Colliery. PhD Thesis, MS VŠB-TU Ostrava, 121 pp., (in Czech).

Ptáček, J., Grygar, R., Koníček, P., Souček, K., Staš, L. and Waclawik, P.: 2009, Verification of Recent-StressStrain in Czech part of Upper Silesian Coal basin, In Documenta Geonica 2009, 2. Ostrava, Ústav geoniky AV ČR, 181-189.

Ptáček, J., Grygar, R., Koníček, P.and Waclawik, P.: 2012, The impact of Outer Western Carpathian nappe tectonics on the stress-strain state in the Upper Silesian Coal Basin (Moravosilesian Zone, Bohemian Massif). Geologica Carpathica, 63-1, 3-11. DOI: 10.2478/v10096-012-0002-X

Ratschbacher, L.,W. Frisch, H., Linzer, G. and Merle, O.: 1991, Lateral extrusion in the Eastern Alps, Part 2: Structural analysis. Tectonics, 10(2), 257-271.

Schreurs, G. and Colletta, B.: 2002, Analogue modelling of continental transpression, In: Schellart W.P. a Passchier C. 2002, Analogue modelling of large-scale tectonic processes. J. Virtual Explorer, 6, 67-78.

Staš, L., Rakowski, Z., Hortvik, K. and Souček, K.: 1997, Measurement of primary horizontal stress in the Czech part of Upper Silesian Coal Basing using hydrofrac method, In Kaláb Z. (ed), 1997: Results of new seismological and geophysican studies, Ústav Geoniky AV ČR, Ostrava, 248-256.

Staš, L., Souček, K., Hortvík, K. and Šimkovičová, J.: 1999, Measurements of primary horizontal stresses in the Czech part of Upper Silesian Basin by using the borehole wall hydrofracturing. In Publications of the Institute of Geophysics Polish Academy of Sciences. Mining Geophysics.. Warszawa: PAN Instytut geofizyki.

Staš, L. and Souček, K.: 2002, Horizontal stress field of carboniferous massif in Eastern Czech part of the Upper Silesian Basin, In ISRM Regional Symposium Advancing Rock Mechanics Frontiers to meet the Challenges of 21st Century. Proceedings, New Delhi : Central Board of Irrigation and Power, 1-10. 
Staš, L., Kolcun, A., Šimkovičová, J. and Souček, K.: 2003, Horizontal stress in the Czech part of the Upper Silesian Coal Basin. In Mineral Raw Materials and Mining Activity of the 21st Century 2, Ostrava, VŠBTU, 579-585, (in Czech).

Waclawik, P.: 2009, Genesis of the overthrust deformations in the Variscan accretion wedge in the Eastermost part of Karviná Subbasin. PhD thesis, MS VŠB-TU Ostrava, 116, (in Czech).

Wilkerson, M.C., Alotria, T. and Farid, T.: 2002, Interpreting the geologic map expression of contractional fault-related fold terminations: laterál/oblique ramps versus displacement gradients. J. Struct. Geol., 24, 593-607. 

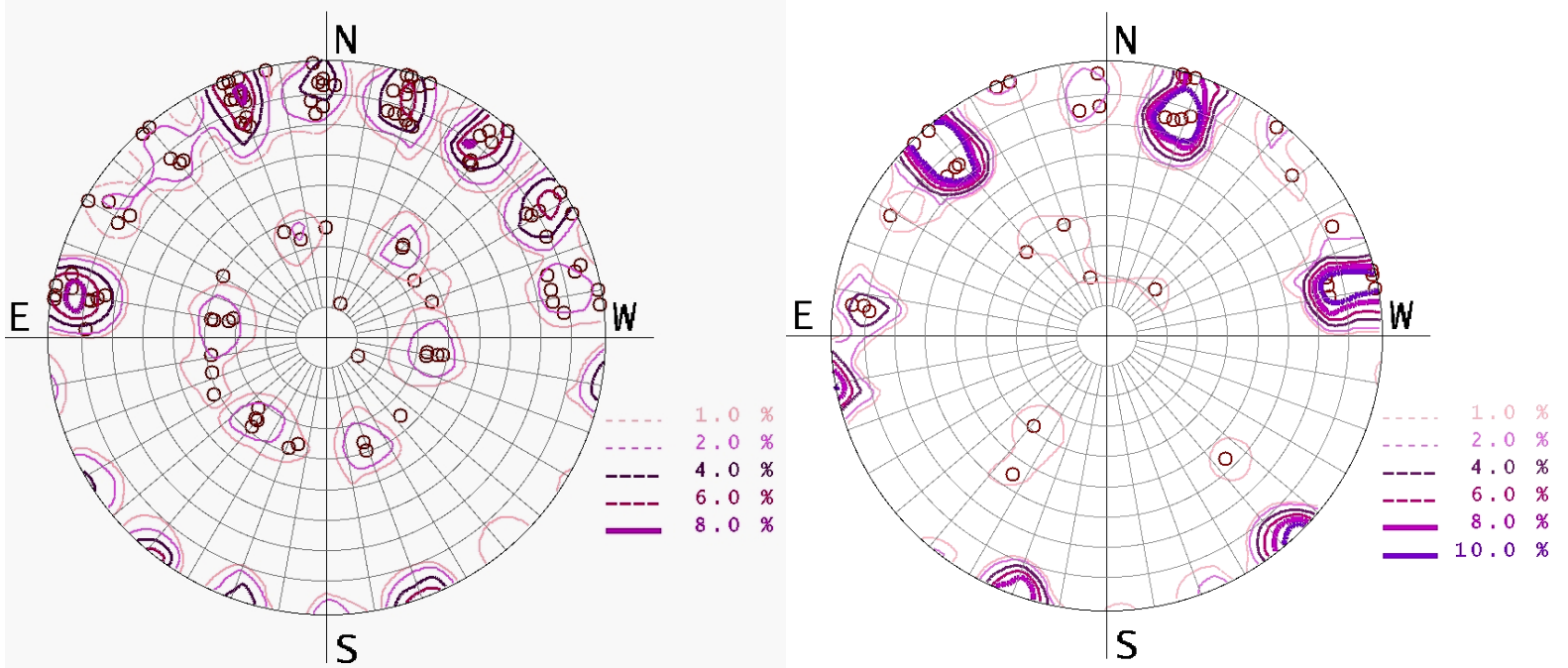

Fig. 2 Diagram of the poles of shear planes (lower hemisphere projection) during the rock burst on July $12^{\text {th }}$ 2011 (on the left) and July $14^{\text {th }} 2011$ (on the right).

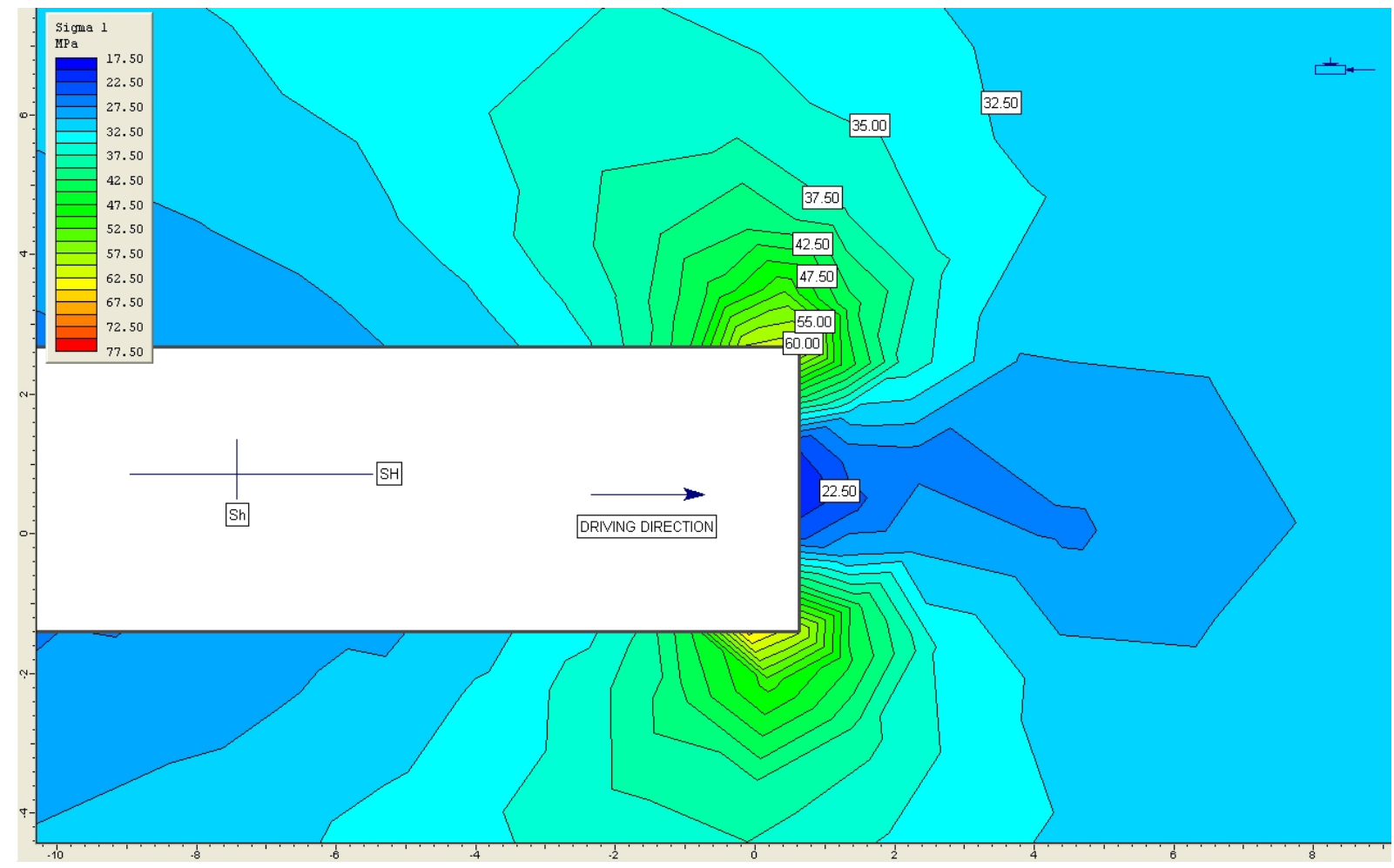

Fig. 5 Distribution of the maximum principal stress on the driving face driven parallelly to the maximum horizontal stress component ( $\mathrm{SH}$ - maximum horizontal stress component direction, $\mathrm{Sh}$ - minimum horizontal stress component direction). 


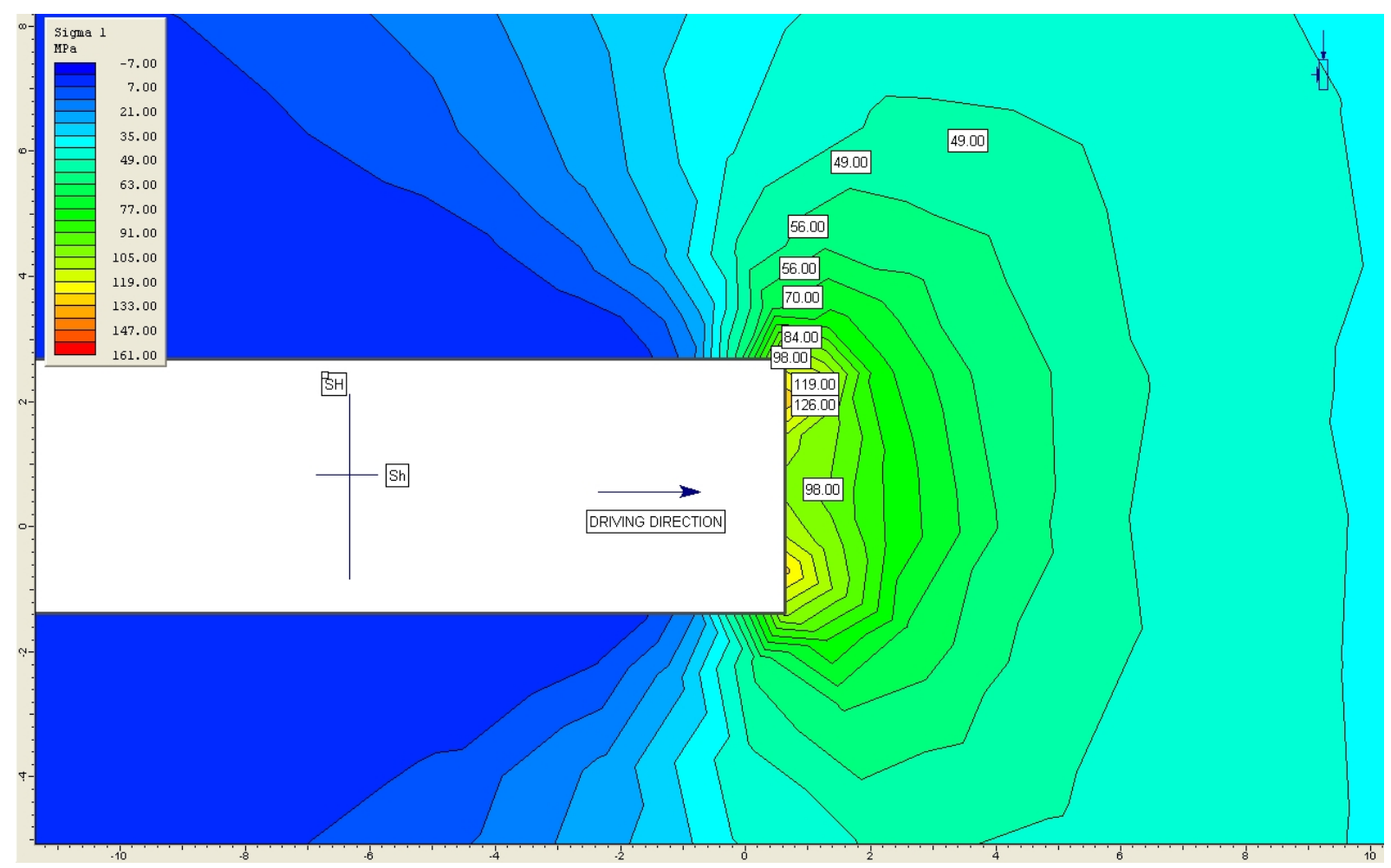

Fig. 6 Distribution of the maximum principal stress on the driving face driven perpendicular to the maximum horizontal stress component ( $\mathrm{SH}$ - maximum horizontal stress component direction, $\mathrm{Sh}$ - minimum horizontal stress component direction).

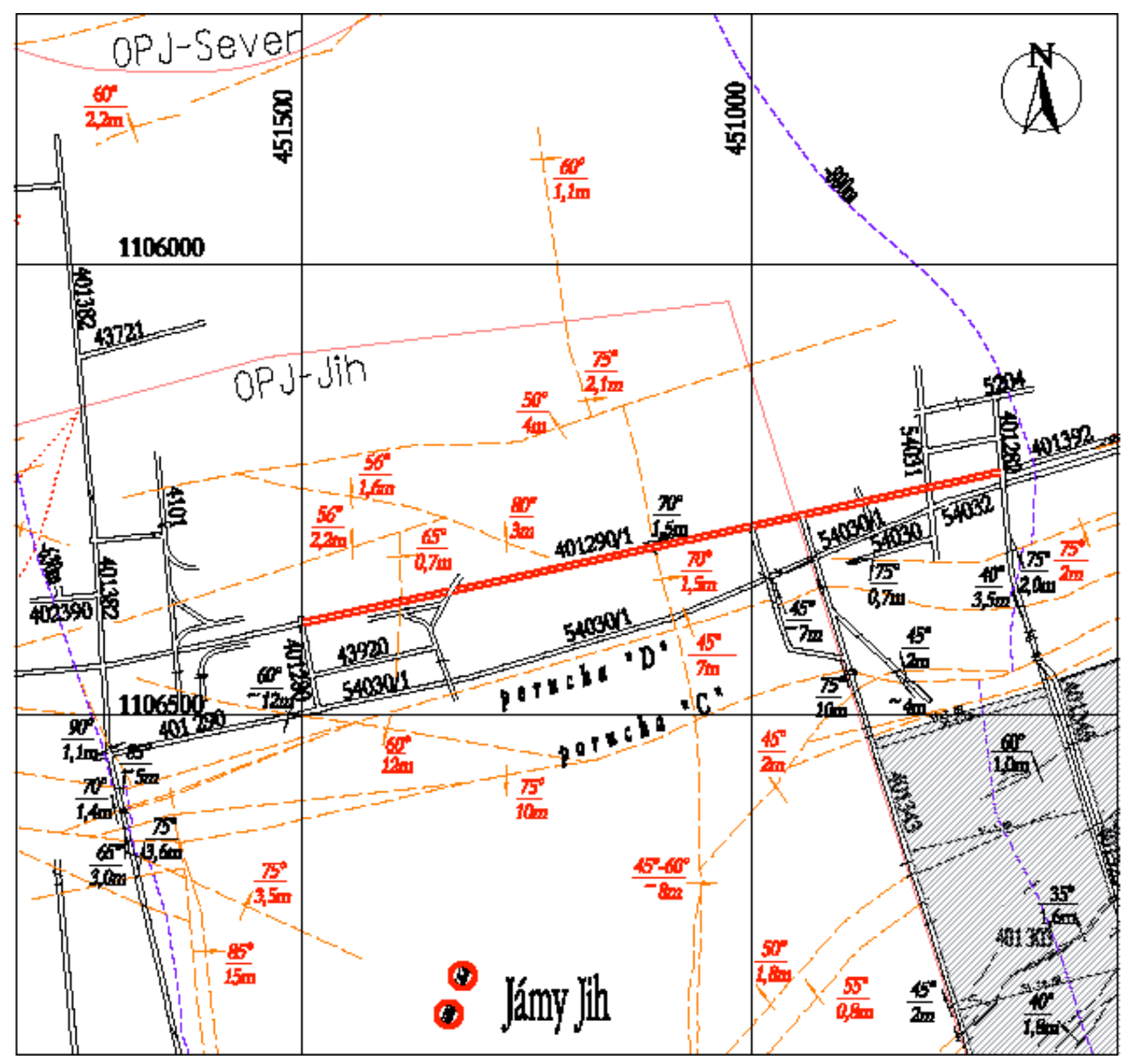

Fig. 7 Drivage of the roadway No. $401290 / 1$ in seam No. 39a+40 in CSM mine. 